\title{
Kajian Kesesuaian, Daya Dukung dan Aktivitas Ekowisata di Kawasan Mangrove Lantebung Kota Makassar
}

\author{
Rini $^{1}$, Isdradjat Setyobudiandi ${ }^{2}$, M. Mukhlis Kamal3 \\ ${ }^{1}$ Institut Pertanian Bogor, rini_usmant@apps.ipb.ac.id \\ ${ }^{2}$ Institut Pertanian Bogor, isdrajad@ipb.ac.id \\ ${ }^{3}$ Institut Pertanian Bogor, m_mukhliskamal@yahoo.com
}

\begin{abstract}
ABSTRAK
Kawasan ekosistem mangrove Lantebung merupakan contoh kawasan rehabilitasi mangrove yang cukup berhasil sejak tahun 2010 hingga sekarang. Kini, ekowisata mangrove akan dikembangkan sebagai bentuk pengelolaan yang tepat untuk menjamin keberlanjutan konservasi dan rehabilitasi sekaligus mendorong ekonomi masyarakat lokal. Sehingga, tujuan penelitian ini adalah menghitung indeks kesesuaian wisata, menghitung daya dukung kawasan dan mengidentifikasi kegiatan ekowisata yang dapat dilakukan di dalam kawasan. Perhitungan indeks kesesuaian kawasan menggunakan rumus $\mathrm{IKW}=\left[\sum \mathrm{Ni} / \mathrm{Nmaks}\right] \times 100 \%$, perhitungan daya dukung kawasan dengan menggunakan rumus DDK $=\mathrm{K} \times[\mathrm{Lp} / \mathrm{Lt}] \mathrm{x}[\mathrm{Wt} / \mathrm{Wp}]$ dan identifikasi kegiatan ekowisata dilakukan dengan identifikasi visual dan wawancara. Hasil penelitian menunjukkan bahwa kawasan mangrove Lantebung sesuai (S) untuk kegiatan wisata dengan nilai kesesuaian sebesar 66,67\%. Panjang kawasan yang dapat dimanfaatkan $2 \mathrm{~km}$ atau seluas 12 ha dan daya dukung sebesar 182 orang/hari (buka 8 jam/hari), jika berdasarkan pada jam buka pengelola (12 jam/hari) maka daya dukungnya menjadi 274 orang/hari. Untuk jenis kegiatan wisata yang dapat dilakukan berjumlah 7 kegiatan, yaitu fotografi (photography), tracking, pengamatan satwa burung (bird watching), pengamatan mangrove (education), pembibitan (education), wisata perahu (boating) dan menikmati suasana matahari tenggelam.
\end{abstract}

Kata kunci: daya dukung kawasan, ekowisata mangrove, indeks kesesuaian wisata, Lantebung

\section{ABSTRACT}

Ecosystem mangrove of Lantebung is an example of mangrove rehabilitation area which is quite successful since 2010 until now. Now, mangrove ecotourism will be developed as an appropriate form of management to ensure the sustainability of conservation and rehabilitation while driving the economy of local communities. Thus, purposes of this study are to calculate the tourist suitability index, calculate the carrying capacity and to identify of ecotourism activities that can be done within the area. The calculation of suitability index using the formula IKW $=[\Sigma \mathrm{Ni} / \mathrm{Nmaks}] \times 100 \%$, calculation of carrying capacity using $D D K=K \times[L p / L t] x[W t / W p]$ and identification of ecotourism activities conducted with visual identification and interview. The results showed that the suitable mangrove area of Lantebung is suitable (S) for tourism activities with a value of suitability of $66.67 \%$. The length of the area can be used $2 \mathrm{~km}$ or $12 \mathrm{ha}$ and its carrying capacity is 190 persons/day (open 8 hours/day), if based on the management hours (12 hours/day) then its carrying capacity is 286 persons/day. Type of ecotourism activities that can be done totaling 7 activities, namely photography, tracking, bird watching, mangrove observation (education), seeds nursery (education), boat tours and enjoy the sunset.

Keywords: carrying capacity, mangrove ecotourism, tourism suitability index, Lantebung 
Naskah Masuk : 19 Februari 2018

Naskah Direvisi: 22 Februari 2018

Naskah Diterima : 6 April 2018

\section{PENDAHULUAN}

Kota Makassar merupakan ibu kota provinsi Sulawesi Selatan yang memiliki potensi sumber daya pesisir dan pulaupulau kecil yang cukup tinggi. Mulai dari terumbu karang, lamun, mangrove, pantai, sungai, dan estuari. Potensi sumber daya alam tersebut sudah ada yang dikembangkan oleh pemerintah kota, seperti wisata bahari di pulau-pulau kecil.

Kawasan ekosistem mangrove Kota Makassar pada tahun-tahun sebelumnya cukup memprihatinkan. Pada tahun 2001, luas mangrove hanya skeitar 50,30 ha dan pada tahun 2015 mengalami penambahan luas sebesar 58,53 ha atau bertambah sekitar 16\% (Bando et al., 2017). Hal ini terjadi karena berbagai kegiatan konservasi dan penanaman mangrove di wilayah pesisir utara Kota Makassar telah dilakukan oleh berbagai pihak.

Kawasan mangrove Lantebung merupakan sisa jalur hijau yang kini ditetapkan sebagai kawasan konservasi dan perlindungan ekosistem pesisir berupa kawasan mangrove (BPPD, 2015). Sejak tahun 2010 pemerintah Makassar dan masyarakat telah melakukan kegiatan penanaman mangrove di sepanjang pesisir Lantebung. Sehingga banyak anakan mangrove ditemukan di bagian bibir pantai. Untuk mendukung keberlanjutan konservasi mangrove di kawasan ini, pemerintah mencanangkan ekosistem mangrove Lantebung sebagai kawasan ekowisata.

Kemudian adanya bantuan dari CCDPIFAD berupa jalur tracking sepanjang 280 $m$ dan pondok informasi wisata menjadi penanda direalisasikannya rencana tersebut. Tuwo (2011) berpendapat bahwa pengembangan ekowisata merupakan salah satu alternatif pembangunan yang dapat membantu mengatasi masalah pemanfaatan yang sifatnya merusak dan mengancam kelestarian sumber daya.

Pemanfaatan wilayah pesisir dengan pengembangan ekowisata maka pemahaman mengenai daya dukung kawasan perlu diperhatikan, mengingat prinsip ekowisata menurut Bjork (2000) bahwa ekowisata merupakan bentuk wisata yang tidak melampaui daya dukung suatu kawasan. Perhitungan daya dukung kawasan dimaksudkan untuk membatasi pemanfaatan yang berlebihan dan mencegah kerusakan ekosistem (Nugraha et al., 2013).

The International Ecotourism SocietyTIES (1991) memberikan defenisi ekowisata adalah suatu bentuk perjalanan yang bertanggung jawab ke daerah alami yang lingkungannya dilindungi dan mampu meningkatkan kesejahteraan penduduk lokal. Bentuk perjalanan yang bertanggung jawab dapat dimaknai sebagai kegiatan wisata yang tidak memberikan merusak lingkungan, sehingga aktivitas dalam ekowisata seminimal mungkin tidak mengeksploitasi sumber daya.

Tujuan penelitian ini adalah untuk menghitung indeks kesesuaian kawasan untuk pengembangan ekowisata mangrove, menghitung daya dukung kawasan dan mengidentifikasi jenis kegiatan wisata yang dapat dilakukan dalam kawasan mangrove

\section{KAJIAN LITERATUR \\ Kajian Kesesuaian Ekowisata}

Pengembangan wisata mangrove memerlukan kesesuaian sumber daya dan lingkungan yang sesuai dengan yang disyaratkan. Kesesuaian karakteristik sumber daya dan lingkungan untuk pengembangan wisata dilihat dari aspek keindahan alam, keamanan dan keterlindungan kawasan, keanekaragaman biota, keunikan sumber daya dan aksesibilitas. Yulianda (2010) menyatakan bahwa wisata mangrove merupakan bentuk wisata pantai yang kegiatannya menikmati alam habitat mangrove. Jenis wisata ini mensyaratkan:

1. Ketebalan mangrove, dimana ketebalan mangrove diukur dari garis terluar ke arah laut tegak lurus ke arah 
darat hingga vegetasi mangrove berakhir

2. Kerapatan mangrove, dimana jumlah pohon mangrove menunjukkan daya dukung kawasan dan kenyamanan habitat

3. Jenis mangrove, dimana jenis mangrove mempunyai pemandangan dan kenyaman bagi pengunjung

4. Pasang surut, dimana ketinggian air dan frekuensi pasang air laut ikut menentukan kenyamanan wisata

5. Obyek biota, dimana keragaman biota seperti ikan, kepiting, moluska, mamalia dan burung menambah nilai daya tarik di habitat mangrove.

\section{Kajian Daya Dukung}

World Trade Organization (WTO) mendefenisikan daya dukung adalah jumlah maksimum orang yang dapat mengunjungi suatu objek wisata pada saat yang sama tanpa menyebabkan kerusakan fisik, ekonomi atau sosial budaya dan hal yang menyebabkan berkurangnya kualitas kepuasan pengunjung (PAC/RAC, 2003).

Mengingat pengembangan ekowisata tidak bersifat mass tourism dan ruang untuk pengunjung terbatas, maka perlu dilakukan perhitungan daya dukung kawasan. Daya dukung kawasan ini menurut konsep yang dikembangkan Yulianda (2007) mempertimbangkan luas atau panjang kawasan dan lama pemanfaatan kawasan itu sendiri.

\section{Ekowisata Mangrove}

Wisata mangrove termasuk dalam kategori wisata pantai, yang aktivitasya terbatas pada ekosistem mangrove itu sendiri. Wahyuni et al. (2007) menyebutkan bahwa ada 7 program ekowisata yang dikembangkan dalam kawasan ekowisata Tahura Ngurah Rai yaitu mangrove education \& tour, program bird watching, program fishing, program mangrove tree plantation or adaptation, program canoeing dan program boating.

\section{METODE PENELITIAN}

\section{Waktu dan Tempat Penelitian}

Penelitian dilaksanakan pada bulan Oktober-November 2017 di kawasan ekosistem mangrove Lantebung, Keluarahan Bira, Kota Makassar yang sedang dikembangkan sebagai destinasi wisata baru. Penentuan stasiun pengamatan dilakukan dengan metode purposive sampling sebanyak 4 titik stasiun. Pemilihan stasiun tersebut dilakukan dengan pertimbangan perbedaan ketebalan mangrove, mengingat ketebalan mangrove merupakan parameter utama dalam kesesuaian wisata.

\section{Sumber Data}

Jenis data yang digunakan dalam penelitian ini adalah data primer dan sekunder. Data primer yang digunakan yaitu data jenis vegetasi, kerapatan mangrove dan fauna asosiasi yang dijadikan salah satu objek wisata. Sedangkan data sekunder terdiri dari data ketebalan mangrove, panjang kawasan ekosistem mangrove dan pasang surut. Data sekunder diperoleh dari Stasiun Meteorologi Maritim Paotere Makassar, analisis citra dan referensi penelitian terkait.

\section{Prosedur Penelitian}

\section{Survei Awal}

Tahapan ini dilakukan untuk mendapatkan gambaran awal mengenai lokasi penelitian. Survei ini dilakukan dengan pengamatan visual terhadap jenis mangrove dan faunanya, panjang kawasan, suasana, fasilitas dan identifikasi responden.

\section{Pengumpulan Data}

Data ekologi yang dikumpulkan terdiri dari sebagai berikut:

\section{Ketebalan dan Panjang Kawasan Mangrove}

Ketebalan mangrove dihitung dengan menggunakan analisis citra Google Earth perekaman tanggal 30 Agustus 2017.

\section{Kerapatan dan Jenis Mangrove}

Pengambilan data jenis dan kerapatan mangrove dilakukan dengan metode kombinasi antara metode jalur dan metode garis berpetak yang diletakkan tegak lurus garis pantai menuju daratan dengan 3 plot pada setiap stasiunnya.

\section{Pasang Surut}

Data pasang surut tahun 2017 diperoleh dari Stasiun Meteorologi Maritim Paotere Makassar.

\section{Obyek Wisata}

Obyek wisata yang terdiri dari biota asosiasi dilakukan bersamaan dengan 
pengamatan vegetasi mangrove dengan metode pengamatan langsung.

\section{Identifikasi Aktivitas Ekowisata}

Identifikasi aktivitas ekowisata dilakukan dengan identifiksi visual terhadap atraksi wisata yang dianggap menarik dan wawancara terhadap pengunjung dan ketua kelompok pengelola. Penentuan responden menggunakan teknik wawancara accidental sampling dengan nilai $\mathrm{n}>30$ orang (Muhajirin et al., 2010).

\section{Analisis Data}

\section{Perhitungan Kesesuaian Kawasan}

Menurut Yulianda (2007), kesesuaian wisata mangrove mempertimbangkan lima parameter. Parameter tersebut adalah ketebalan mangrove (m), kerapatan mangrove (ind $/ 100 \mathrm{~m}^{2}$ ), jenis mangrove, pasang surut $(\mathrm{m})$ dan obyek wisata (Tabel 1).

Untuk menghitung indeks kesesuaian kawasan untuk wisata mangrove, digunakan persamaan berikut:

dimana:

$$
I K W=\left(\frac{\sum N i}{N m a k s}\right)
$$

IKW =indeks kesesuaian wisata

$\mathrm{Ni}=$ nilai parameter $\mathrm{ke}-i$ (bobot $\mathrm{x}$ skor)

Nmaks =nilai maksimum dari suatu kategori wisata

Tingkat kesesuaian kawasan dibagi menjadi empat klasifikasi, yaitu:

S1 = sangat sesuai, dengan nilai 75$100 \%$

S2 = sesuai, dengan nilai $50-74 \%$

S3 = sesuai bersyarat, dengan nilai $25-49 \%$
$\mathrm{N}=$ tidak sesuai, dengan nilai $<25 \%$

\section{Perhitungan Daya Dukung Kawasan}

Daya dukung kawasan dihitung berdasarkan rumus yang dikemukakan oleh Yulianda (2007), yaitu:

dimana:

$$
D D K=K x\left(\frac{L p}{L t}\right) x\left(\frac{W t}{W p}\right)
$$

DDK =daya dukung kawasan (orang/hari)

$\mathrm{K} \quad$ = potensi ekologis pengunjung per satuan unit area (orang)

$\mathrm{Lp} \quad=$ luas atau panjang area yang dapat dimanfaatkan ( $\mathrm{m}$ atau $\mathrm{m}^{2}$ )

$\mathrm{Lt}=$ unit area untuk kategori tertentu $\left(\mathrm{m}\right.$ atau $\mathrm{m}^{2}$ )

$\mathrm{Wt}=$ waktu yang disediakan oleh kawasan untuk kegiatan wisata dalam satu hari (jam)

$\mathrm{Wp}=$ waktu yang dihabiskan oleh pengunjung untuk setiap kegiatan tertentu (jam)

Menurut Yulianda (2010), potensi ekologis (K) pengunjung ditentukan oleh kondisi sumber daya dan jenis kegaiatan yang akan dikembangkan. Luas area (Lt) yang dapat digunakan oleh pengunjung dengan mempertimbangkan kemampuan alam mentolerir pengunjung sehingga keaslian alam tetap terjaga (Tabel 2).

Waktu pengunjung (Wp) dihitung berdasarkan pada berapa lama pengunjung menghabiskan waktu dalam kawasan wisata. Sedangkan waktu yang disediakan oleh kawasan untuk pengunjung disesuaiakan dengan berapa lama area wisata dibuka selama satu hari (Wt) (Tabel 2).

Tabel 1

Matriks Kesesuaian Lahan untuk Wisata Mangrove

\begin{tabular}{lccccccccc}
\hline \multirow{2}{*}{ Parameter } & \multirow{2}{*}{ Bobot } & \multicolumn{8}{c}{ Kelas kesesuaian (skor) } \\
\cline { 2 - 9 } & & S1 & Skor & S2 & Skor & S3 & Skor & N & Skor \\
\hline Ketebalan & 5 & $>500$ & 3 & $>200-$ & 2 & $50-200$ & 1 & $<50$ & 0 \\
mangrove & & & & 500 & & & & &
\end{tabular}

(m)

\begin{tabular}{lccccccccc}
\hline $\begin{array}{l}\text { Kerapatan } \\
\text { mangrove } \\
\left(100 \mathrm{~m}^{2}\right)\end{array}$ & 3 & $>15-25$ & 3 & $>10-15$ & 2 & $5-10$ & 1 & $<5$ & 0 \\
$\begin{array}{l}\text { Jenis } \\
\text { mangrove }\end{array}$ & 3 & $>5$ & 3 & $3-5$ & 2 & $1-2$ & 1 & 0 & 0 \\
\hline
\end{tabular}


Jurnal Pariwisata, Vol. 5 No.1 April 2018

\begin{tabular}{|c|c|c|c|c|c|c|c|c|c|}
\hline $\begin{array}{l}\text { Pasang } \\
\text { surut }(\mathrm{m})\end{array}$ & 1 & $0-1$ & 3 & $>1-2$ & 2 & $>2-5$ & 1 & $>5$ & 0 \\
\hline Obyek biota & 1 & $\begin{array}{l}\text { Ikan, } \\
\text { udang, } \\
\text { kepiting, } \\
\text { moluska, } \\
\text { reptil, } \\
\text { burung }\end{array}$ & 3 & $\begin{array}{c}\text { Ikan, } \\
\text { udang, } \\
\text { kepiting } \\
\text { moluska }\end{array}$ & 2 & $\begin{array}{c}\text { Ikan, } \\
\text { moluska }\end{array}$ & 1 & $\begin{array}{c}\text { Salah } \\
\text { satu } \\
\text { biota } \\
\text { air }\end{array}$ & 0 \\
\hline
\end{tabular}

Tabel 2

Potensi Ekologis (K), Panjang Area Pengunjung (Lt), Waktu yang Disediakan (Wt) dan Waktu yang Dihabiskan Pengunjung (Wp)

\begin{tabular}{|c|c|c|c|c|}
\hline Kegiatan & $\begin{array}{c}\text { K } \\
\text { (Epengunjung) }\end{array}$ & $\begin{array}{c}\text { Panjang area } \\
(L t)\end{array}$ & $\begin{array}{c}\text { Waktu yang } \\
\text { dihabiskan } \\
\text { Wp (jam) }\end{array}$ & $\begin{array}{c}\text { Waktu yang } \\
\text { disediakan } 1 \text { hari } \\
\text { Wt (jam) }\end{array}$ \\
\hline $\begin{array}{l}\text { Wisata } \\
\text { mangrove }\end{array}$ & 1 & $\begin{array}{l}50 \mathrm{~m} \text { (dihitung } \\
\text { panjang track, } \\
\text { setiap } 1 \text { orang } \\
\text { sepanjang } 50 \mathrm{~m} \text { ) }\end{array}$ & 2 & 8 \\
\hline
\end{tabular}

Sumber: Yulianda (2007)

\section{PEMBAHASAN}

\section{Gambaran Umum Lokasi Penelitian}

Secara administratif, Lantebung termasuk dalam wilayah Kelurahan Bira Kecamatan Tamalanrea. Secara geografis berbatasan dengan Kelurahan Untia sebelah utara, Kelurahan Parangloe sebelah selatan, Kelurahan Bulurokeng sebelah timur dan Selat Makassar sebelah barat. Kelurahan Bira merupakan kelurahan terluas di Kecamatan Tamalanre dengan luas 9,28 $\mathrm{km}^{2}$ dan termasuk daerah pantai dengan ketinggian wilayah $1-22 \mathrm{~m}$ di atas permukaan laut (BPS Kota Makassar, 2017).

\section{Iklim dan Cuaca}

Iklim di Kelurahan Bira merupakan iklim tropis. Rerata suhu dan kelembaban udara adalah $28,4^{\circ} \mathrm{C}$ dan $81 \%$, kecepatan angin rata-rata 44 knot, curah hujan tertinggi berada pada bulan Februari yaitu $724 \mathrm{~mm}^{3}$ dengan jumlah hari hujan tertinggi pada bulan Desember yaitu 27 hari dan curah hujan terendah pada bulan Agustus yaitu 0 $\mathrm{mm}^{3}$ dan jumlah hari hujan 1 hari (BPS Kota Makassar, 2017).

\section{Kesesuaian Kawasan untuk Ekowisata} Indeks kesesuaian wisata mangrove terdiri dari ketebalan mangrove (m), kerapatan jenis mangrove (ind $/ 100 \mathrm{~m}^{2}$ ), pasang surut (m) dan obyek biota.

\section{Ketebalan Mangrove}

Perhitungan ketebalan mangrove dilakukan pada 4 titik stasiun dengan menganalisis citra satelit Google Earth (perekaman 30 Agustus 2017). Hasil analisis menunjukkan bahwa ketebalan mangrove di setiap stasiun berkisar 119 - $163 \mathrm{~m}$ dengan ratarata 144,5 $\mathrm{m}$ (Tabel 1). Ketebalan mangrove di setiap stasiun termasuk dalam kategori S3 yaitu sesuai bersyarat untuk wisata.

\section{Jenis dan Kerapatan Mangrove}

Jenis mangrove yang ditemukan pada lokasi penelitian sebanyak 7 jenis, terdiri dari 3 jenis mangrove sejati dan 4 jenis flora asosiasi mangrove. Spesies mangrove sejati yang ditemukan yaitu Avicennia marina, Avicennia alba dan Rhizphora mucronata. Sedangkan spesies flora asosiasi mangrove ditemukan yaitu Acanthus ebracteatus (Jeruju putih), Sesuvium portulacastrum (Gelang laut), Acrostichum aureum (Paku Laut) dan 
Hibiscus tiliaceus (Waru Laut). Selain spesies mangrove yang ditemukan, terdapat juga spesies Rhizophora apiculata yang tidak ditemukan di stasiun pengamatan namun ditemukan oleh Bando et al. (2017).

Hasil analisis data vegetasi dengan ukuran plot $10 \times 10 \mathrm{~m}$ diperoleh data kerapatan pohon mangrove rata-rata di kawasan mangrove Lantebung adalah 22 individu $/ 100 \mathrm{~m}^{2}$ (Tabel 1) dan termasuk dalam kategori S2 yaitu sesuai untuk wisata.

\section{Pasang Surut Perairan Kota Makassar}

Data pasang surut yang diperoleh menunjukkan bahwa rata-rata pasang surut perairan Kota Makassar pada tahun 2017 adalah $0,8 \mathrm{~m}$. Pasang surut tertinggi terjadi di bulan Februari yaitu 1,3 m dan terendah di bulan Oktober yaitu 0,5 m (Gambar 1). Hal ini menujukkan bahwa pasang surut perairan termasuk dalam kategori S1 yaitu sangat sesuai untuk wisata.

\section{Objek biota}

Mangrove merupakan daerah asuhan (nusery ground), daerah mencari makanan (feeding ground) dan daerah pemijahan (spawning ground) berbagai jenis ikan, udang, kepiting dan biota laut lainnya. Serta tempat berlindung dan berkembangbiaknya berbagai jenis burung dan binatang mamalia lainnya. Pada ekosistem mangrove Lantebung ditemukan berbagai jenis biota. Untuk jenis burung yang diidentifikasi terdapat 5 jenis yaitu Kowak Malam Kelabu (Nycticorax nycticorax), Kuntul Kecil (Egretta garzetta), Kokokan Laut (Butorides striata), Blekok Sawah (Ardeola speciosa) dan Walet (Collacalia fluciphaga). Khusus untuk burung Kuntul Kecil (Egretta garzetta) merupakan spesies burung yang dilindungi di Indonesia berdasarkan UU No. 5 Tahun 1990 tentang konservasi keanekaragaman hayati dan ekosistenya dan PP No. 7 Tahun 1999 tentang pengawetan jenis tumbuhan dan satwa. Jenis reptil terdiri dari dua yaitu Biawak (Varanus salvatoe) dan Ular. Jenis ikan yaitu Ikan Glodok (Periophthalmus spilotus). Jenis moluska terdiri dari 8 jenis yaitu Siput Belongkeng (Ellobium sp.), Ellobium aurijudae, Telecopium Telescopium, Terebralia sulcate, Cassidula aurisflis, Cerithidea cingulate, Cassidula sp. dan Pugilina cochilidium. Jenis Kepiting ditemukan 3 jenis yaitu Kepiting Pemanjat (Episesarma sp.), Kepiting Ungu Pemanjat (Metopograpsus sp.) dan Uca $s p$ (Gambar 2).

\section{Perhitungan Tingkat Kesesuaian}

Perhitungan dari masing-masing parameter tersebut diatas kemudian dibuat dalam suatu matriks kesesuaian wisata seperti pada Tabel 3.

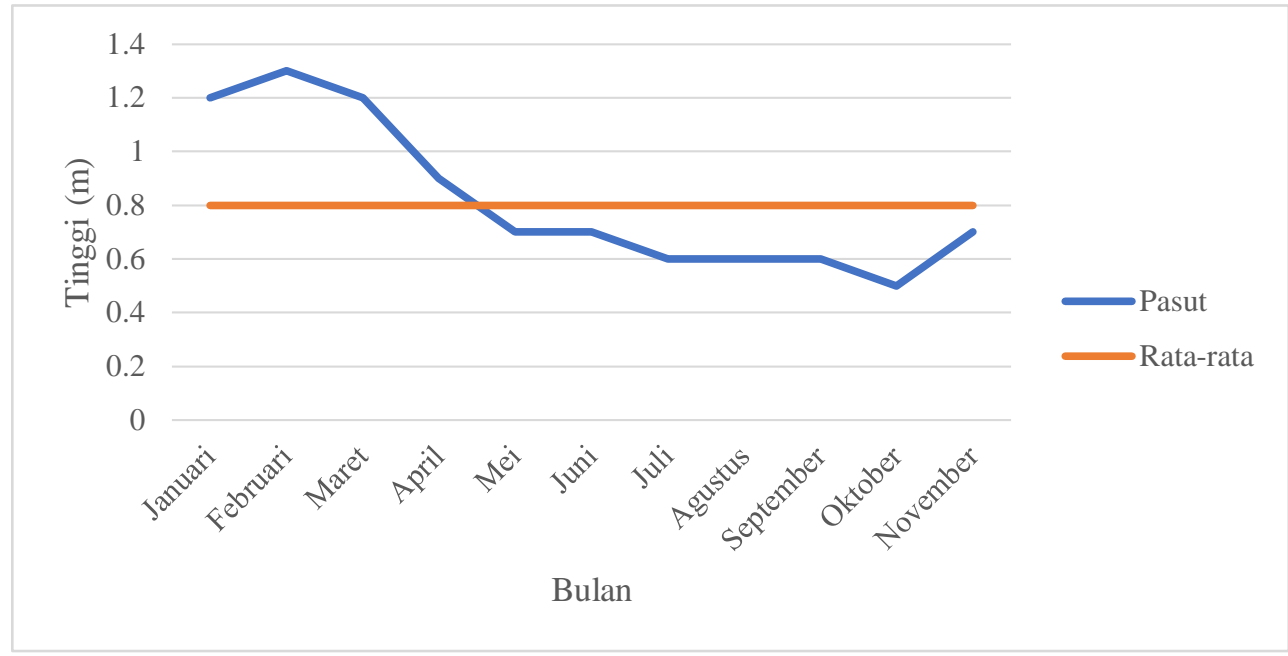

Gambar 1

Grafik Pasang Surut Perairan Kota Makassar Tahun 2017

(Sumber: Stasiun Meteorologi Maritim Paotere Makassar, diolah) 


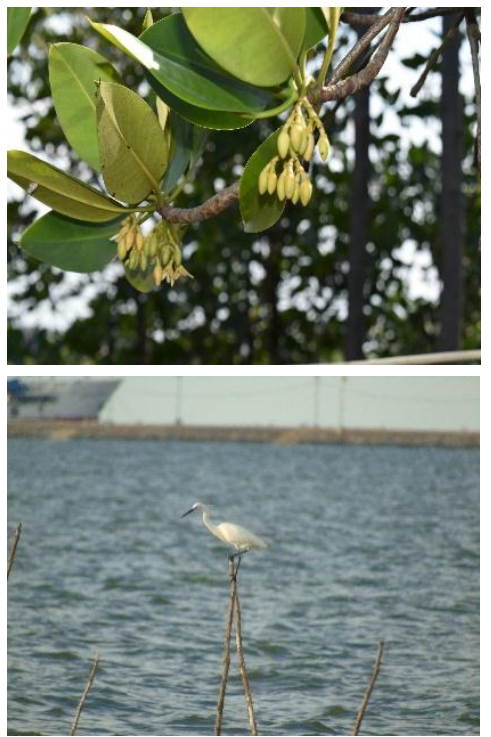

Gambar 2
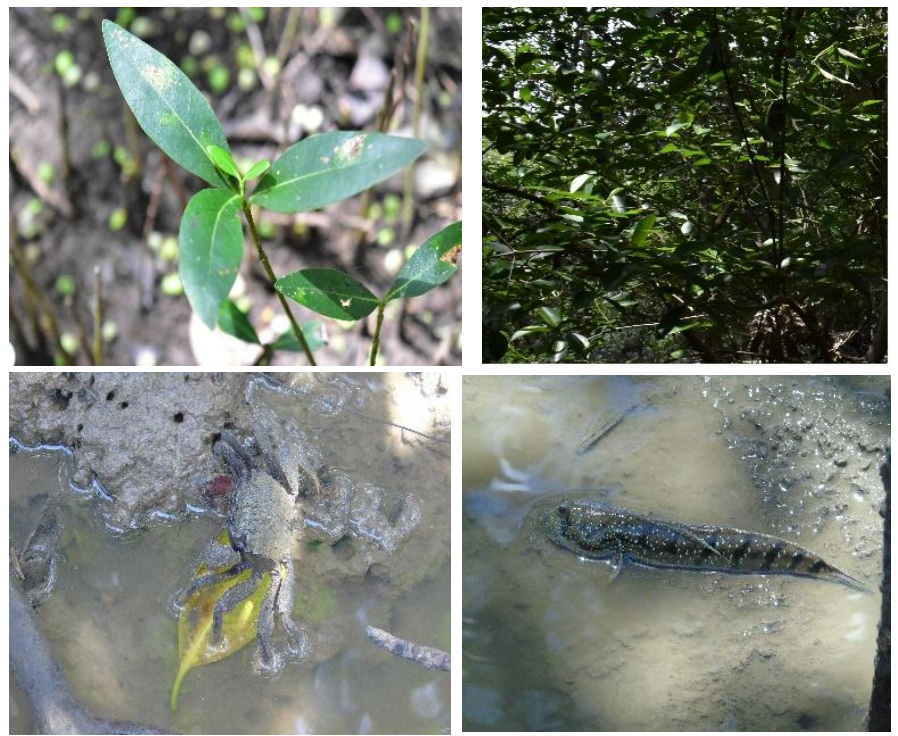

Jenis Mangrove dan Obyek Biota yang Ditemukan di Ekosistem Mangrove Lantebung

Tabel 3

Matriks Kesesuaian Wisata Mangrove

\begin{tabular}{lcccc}
\hline \multicolumn{1}{c}{ Parameter } & Bobot & Kategori & Skor & Nilai \\
\hline Ketebalan mangrove $(\mathrm{m})$ & 5 & $\mathrm{~S} 3$ & 1 & 5 \\
\hline Kerapatan mangrove $\left(\mathrm{ind} / 100 \mathrm{~m}^{2}\right)$ & 3 & $\mathrm{~S} 1$ & 3 & 9 \\
\hline Jenis mangrove & 3 & $\mathrm{~S} 2$ & 2 & 6 \\
\hline Pasang surut $(\mathrm{m})$ & 1 & $\mathrm{~S} 1$ & 3 & 3 \\
\hline Obyek biota & 1 & $\mathrm{~S} 1$ & 3 & 3 \\
\hline & Jumlah & & & 26
\end{tabular}

Nilai matriks kesesuaian kemudian digunakan dalam perhitungan indeks kesesuaian wisata. Berdasarkan perhitungan, secara keseluruhan kawasan mangrove Lantebung memiliki nilai $66,67 \%$ dan termasuk dalam kategori sesuai (S2) untuk dikembangkan sebagai tempat wisata. Kategori sesuai untuk wisata, secara umum, didukung oleh kerapatan jenis, pasang surut dan obyek biota yang memiliki nilai sangat sesuai (S1) dan jenis mangrove yang termasuk kategori sesuai (S2). Namun, secara khusus, perlu diperhatikan bahwa ketebalan mangrove termasuk dalam kategori sesuai bersyarat (S3) yang artinya, ketebalan mangrove di Lantebung masih perlu ditingkatkan melalui upaya penaman oleh masyarakat sekitar dan program rehabilitasi dari pemerintah atau instansi lain. Hal tersebut agar dapat semakin mendukung kegiatan ekowisata.

Berdasarkan hasil wawancara dengan pengelola dan perhitungan luas kawasan dengan perangkat ArcGIS diperoleh bahwa panjang kawasan yang dapat dimanfaatkan adalah $2000 \mathrm{~m}$ dengan luas sebesar 12 ha.

\section{Perhitungan Daya Dukung kawasan}

McNeely (1992) menyatakan bahwa daya dukung wisata merupakan tingkat pengunjung yang memanfaatkan suatu kawasan wisata dengan perolehan tingkat 
kepuasan yang optimal serta dampak terhadap sumberdaya yang minimal. Perhitungan daya dukung kawasan di Lantebung memperhatikan panjang kawasan yang dapat dimanfaatkan dan panjang fasilitas tracking yang telah dibuat sebelumnya oleh pengelola. Hal ini perlu dilakukan karena jalur tracking merupakan spot yang diminati oleh pengunjung sehingga jumlah pengunjung hampir memenuhi sepanjang jalur. Menurut perhitungan daya dukung Yulinda (2007), diketahui bahwa potensi ekologis $(\mathrm{K})$ per satuan unit area untuk wisata mangrove adalah 1 oang untuk track sepanjang $50 \mathrm{~m}$ (Lt). Waktu yang dihabiskan oleh setiap pengunjung untuk berwisata mangrove adalah rerata 2 jam (Wp) dan lama waktu yang disediakan kawasan untuk berwisata 1 hari rerata 8 jam (Wt). Dengan panjang kawasan yang diperuntukkan untuk wisata adalah $2000 \mathrm{~m}(\mathrm{Lt})$, maka jumlah daya dukung kawasan untuk wisata adalah 160 orang/hari dan daya dukung untuk jalur tracking sepanjang $280 \mathrm{~m}$ sebanyak 22 orang/hari. Total daya dukungnya adalah 182 orang per hari.

Namun mengacu pada kondisi nyata lokasi wisata, dimana waktu wisata selama 12 jam (mulai di buka mulai pukul 06.00 dan tutup pukul 18.00), maka jumlah daya dukung kawasan adalah 240 orang/hari dan untuk jalur tracking sebanyak 34 orang/hari. Total daya dukungnya sebanyak 274 orang/hari.

\section{Aktivitas Ekowisata yang Sesuai}

Upaya pengembangan ekowisata mangrove tidak dapat terlepas dari pengaruh masyarakat, pengelola dan pengunjung. Berdasarkan wawancara dengan 35 orang pengunjung mengenai aktivitas ekowisata yang cocok dilakukan di kawasan mangrove Lantebung diperoleh bahwa $100 \%$ memilih fotografi (photography), 8,8\% (3 orang) memilih pengamatan satwa burung (bird watching), $29,4 \%$ (10 orang) memilih pengamatan mangrove (education). Kemudian, wawancara dengan ketua pengelola diperoleh bahwa jasa wisata yang sarankan adalah pembibitan (education), wisata perahu (boating) dan menikmati suasana matahari tenggelam.
Seluruh kegiatan wisata tersebut merupakan kegiatan wisata yang dinginkan oleh pengunjung dan pengelola, namun tidak semua kegiatan tersebut dapat dilakukan setiap kawasan mangrove. Hal ini disebabkan karena kondisi wilayah yang merupakan kawasana rehabilitasi mangrove, sehingga hanya di titik-titik tertentu suatu kegiatan dapat dilakukan. Kecuali, aktivitas fotografi (photography), pengamatan mangrove (education), tracking dan menikmati suasana matahari tenggelam.

Untuk memudahkan dalam perencanaan pengembangan ekowisata maka dibuat perencanaan tata letak aktivitas wisata yang dapat dilakukan sesuai dengan rekomendasi dan kondisi lingkungan. Seperti untuk kegiatan pengamatan satwa burung, direkomendasikan dilakukan di gazebo paling terluar karena lokasinya yang berdekatan dengan spot burung berkumpul pada sore hari. Kemudian jalur tracking mangrove disarankan di sepanjang kawasan mangrove, namun peletakan posisi jalur trackingnya di bagian tengah kawasan. Hal ini dikarenakan, bagian tepi kawasan merupakan daerah mangrove muda dan kondisi substrat yang belum memadat. Untuk wisata perahu (boating) sebelum ditawarkan sebagai jasa wisata harus memperhatikan dahulu jumlah wisatawan per hari yan dapat diterima, hal ini dikarenakan jumlah perahu operasional yang tersedia masih 1 unit. Untuk daerah wisata perahu tersedia di sepanjang sungai kecil dan pantai Lantebung. 


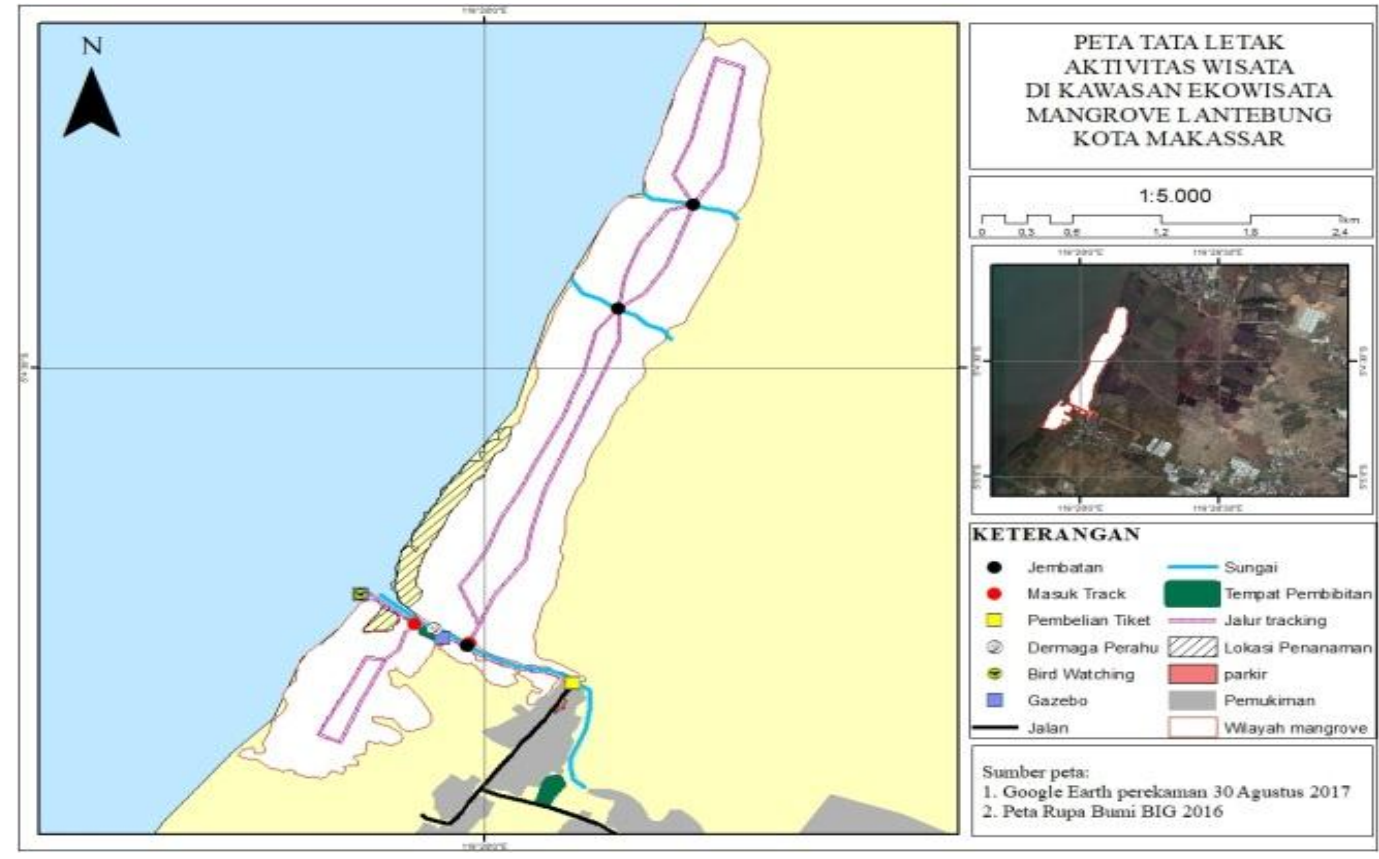

Gambar 3

Peta Kawasan Ekowisata Mangrove

\section{PENUTUP}

\section{Kesimpulan}

Hasil penelitian menunjukkan bahwa kawasan mangrove Lantebung termasuk kategori sesuai (S2) untuk dikembangkan menjadi daerah wisata mangrove dengan nilai indeks kesesuaian yaitu $66,67 \%$. Daya dukung kawasan untuk pengembangan wisata mangrove sebanyak 182 orang per hari. Sedangkan daya dukung berdasarkan kondisi nyata di daerah wisata adalah adalah sebanyak 274 orang per hari. Untuk aktivitas wisata yang sesuai ada 7 yaitu fotografi (photography), tracking, pengamatan satwa burung (bird watching), pengamatan mangrove (education), pembibitan (education), wisata perahu (boating) dan menikmati suasana matahari tenggelam.

\section{Saran}

Untuk mengembangkan ekowisata mangrove yang berkelanjutan yang sesuai daya dukung maka perlu dilakukan perhitungan kembali biaya retribusi kunjungan dan pendataan jumlah pengunjung yang masuk. Selain itu, upaya rehabilitasi dengan mengajak pengunjung berkontirbusi dalam pemeliharaan bibit atau penanaman terus dipromosikan, mengingat ketebalan ekosistem mangrove lantebung masih kecil. Kemudian perlu dilakukan kajian kesesuaian untuk setiap kategori aktivitas wisata dan daya dukungnya.

\section{REFERENSI}

Badan Perencana Pembangunan Daerah (BPPD) Kota Makassar. (2015). Peraturan daerah Kota Makassar Nomor 4 tahun 2015 tentang rencana tata ruang wilayah Kota Makassar tahun 2015-2034. Makassar: BPPD Kota Makassar.

Badan Pusat Statistik (BPS) Kota Makassar. (2017). Kota Makassar dalam angka 2017. Makassar: BPS Kota Makassar.

Bando, A.R., Marsoedi, Susilo A., Tamsil A. (2017). The strategy of mangrove forest management due to mitigation in north coastal area of Makassar. Resources and Environment, 7(2), 31-39.

Bjork P. (2000). Ecotourism From A Conceptual Perspective, An 
Extended Defenition of A Unique

Tourism Form. International

Journal of Tourism Research., 2, 189-202.

McNeely J. (1992). Ekonomi dan keanekaragaman hayati: pengembangan dan pendayagunaan insentif ekonomi untuk melestarikan sumberdaya hayati. (terjemahan dari Economic and biological diversity: Developing and using economics incentives to conserve biological resources). Jakarta: Pustaka Sinar Harapan.

Muhajirin, Wunah S., Rachman T. (2015). Pengembangan sistem transportasi sungai dalam mendukung ekowisata Sungai Tallo Kota Makassar. Jurnal Penelitian Transportasi Multimoda. 13(04), 191-198.

Nugraha, H.P., Indarjo., Helmi M. (2013). Studi kesesuaian dana daya dukung kawasan untuk rekreasi pantai di Pantai Panjang Kota Bengkulu. Journal of Marine Research, 2(2), 130-139.

PAC/RAC. (2003). Guide to good practice in tourism carrying capacity assessment. Split: PAC/RAC.

Tuwo A. (2011). Pengelolaan Ekowisata Pesisir dan Laut: Pendekatan Ekologi, Sosial-Ekonomi, Kelembagaan dan Sarana Wilayah. Surabaya: Brilian Internasional.

The International Ecotourism Society. (1991). Regional prepatory conference for the world ecotourism summit. http://www.ecotourism.org.

Wahyuni P.I., Ardhana, Sunarta I.N. (2007). Evaluasi pengembangan ekowisata di kawasan Tahura Ngurah Rai. Jurnal Ecotrophic, 4(1), 45-56.

Yulianda F. (2007). Ekowisata Bahari sebagai Alternatif Pemanfaatan
Sumberdaya Pesisir Berbasis

Konservasi [Makalah].

Disampaikan pada Seminar Sains

Departemen Manajemen

Sumberdaya Pesisir. Fakultas

Perikanan dan Ilmu Kelautan Institut

Pertanian Bogor. 119-129.

Yulianda F, Fahruddin A, Adrianto L,

Hutabarat A.A, Harteti S,

Kusharjani, Kang HS. (2010).

Pengelolaan Pesisir dan Laut

Terpadu. Bogor: Pusdiklat

Kehutanan-Departemen Kehutanan

RI. Secem-Korea International

Coorperation Agency.

\section{BIODATA PENULIS}

Rini dilahirkan pada tanggal 27 Juli 1992 di Parepare, Sulawesi Selatan. Sejak pendidikan Sekolah Dasar hingga Sekolah Menengah Atas di tamatkan di Kecamatan Suppa. Kemudian melanjutkan Pendidikan S1 pada program studi Pemanfaatan Sumberdaya Perikanan di Universitas Hasanuddin dan lulus pada tahun 2015. Kemudian tahun 2016, melanjutkan pendidikan S2 pada program pascasarjana Ilmu Pengelolaan Sumberdaya Pesisir dan Lautan Institut Pertanian Bogor hingga saat ini dan merupakan penerima beasiswa LPDP Kemenkeu RI tahun 2016. 